$\operatorname{cft} 8$ (revised)

\title{
(Revised)
}

\section{Organizing Innovation: Complementarities Between Cross-Functional Teams}

\author{
James H Love ${ }^{1}$, Stephen Roper ${ }^{2}$ and Giovanni Mangiarotti ${ }^{1}$ \\ ${ }^{1}$ Economics and Strategy Group, Aston Business School, Aston University, \\ Birmingham B4 7ET, UK \\ Email: j.h.love@aston.ac.uk \\ ${ }^{2}$ Centre for Small and Medium-Sized Enterprises,Warwick Business School, \\ University of Warwick, Coventry, CV4 7AL, UK. \\ Email: stephen.roper@wbs.ac.uk
}

\begin{abstract}
Cross-functional teams play a potentially important part in the innovation process enabling knowledge sharing, the development of trust and overcoming spatial and organizational barriers. Using a supermodularity approach, we focus on potential complementarities which may arise when cross-functional teams are used in different elements of the innovation process in UK and German manufacturing plants. Using optimal combinations of cross-functional teams in the innovation process increases innovation success in the UK by 29.5 per cent compared to 9.5 per cent in Germany. Patterns of complementarity are complex, however, but are more uniform in the UK than in Germany. The most uniform complementarities are between product design and development and production engineering, with little synergy evident between the more technical phases of the innovation process and the development of marketing strategy. In strategic terms, our results suggest the value of using cross-functional teams for the more technical elements of the innovation process but that the development of marketing strategy should remain the domain of specialists.
\end{abstract}

JEL Classification: O15, O31, O32

Keywords: Innovation; cross-functional teams; complementarities; UK; Germany

\section{Acknowledgements:}

The research reported in this paper was supported by the ESRC under award RES000-22-0813. This paper was written while Jim Love was a Visiting Professor at Copenhagen Business School. We are grateful to Keld Laursen, Hiro Izushi, two anonymous referees, and discussants and participants at the 2006 DRUID Summer Conference in Copenhagen for constructive comments on earlier drafts. 


\section{Organizing Innovation: Complementarities Between Cross-Functional Teams}

\section{Introduction}

Moves towards knowledge-based competition, and market-leadership based on innovation and product quality rather than cost-competitiveness, have redefined firms' strategy space (Quah, 2001). Externally this has led to increased emphasis on boundary-spanning activities and strategic alliances; internally, the emphasis is increasingly on organizational learning, process optimisation and knowledge sharing. In terms of innovation strategy, in particular, the challenge is how firms best organize the process of sourcing, codifying and exploiting the knowledge and informational resources to which they have access to maximise and sustain innovation ${ }^{1}$. A crucial element in this process of strategy search is the identification and effective harnessing of complementarities between different activities, optimising resource use (Milgrom and Roberts, 1990, 1995) ${ }^{2}$. In terms of human resource management (HRM), for example, Laursen and Foss (2003) consider complementarity between different HRM practices in terms of their impact on innovation outputs (see also Michie and Sheehan, 2003), while in a more general context Lhuillery (2000) examines the impact of a range of organizational practices on the innovation capability of French companies and Labeaga and Martinez Ros (2003) consider complementarity between the decisions to engage in product and process development ${ }^{3}$.

The importance of cross-functional teams is increasingly emphasised in terms of innovation (Rosenberg, 1982; Song et al., 1997), lean production (Levine, 1995; Finegold and Wagner, 1998), and TQM and continuous improvement (see, for example, the references quoted in Hoegl and Gemuenden., 2001, p. 435) ${ }^{4}$. Teams

\footnotetext{
${ }^{1}$ For example, in terms of optimising knowledge sourcing, firms face the classic 'make' or 'buy' tradeoff or, more realistically perhaps, face a choice between conducting in-house R\&D, external R\&D, or both (Veugelers and Cassiman, 1999; Love and Roper, 2002; Cassiman and Veugelers, 2002).

${ }^{2}$ Cassiman and Veugelers (2002), and others, have drawn a parallel between the search for strategic complementarities and notions of strategic 'fit' in the strategic management literature (e.g. Porter, 1996).

${ }^{3}$ Discussion of potential complementarities has not, however, been limited to business strategy. Mohnen and Röller (2005), for example, test the complementarity of a range of innovation policy options, and the issue is considered more generally in terms of micro-economic policy by Stenbacka (2002).

${ }^{4}$ Standard definition of team: 'a team can be defined as a social system of three or more people, which is embedded in an organization (context), whose members perceive themselves as such and are
} 
may facilitate knowledge integration and information exchange (Grabher, 2001), the development of trust and mutual learning (Creed and Miles, 1996), and may be a way of overcoming hierarchical and spatial barriers to project success (Zeller, 2002). Most research on cross-functional teams has, however, focussed on the effectiveness of individual project teams, and the role of either compositional, leadership or environmental factors (e.g. Von Stamm, 2003). Less attention has been paid to the strategic role of such cross-functional teams and, in particular, the potential for generating complementarities between cross-functional teams undertaking different activities. Two activities are complementary if doing more of one activity increases the returns from doing the other. Milgrom and Roberts $(1990,1995)$ developed the formal analysis of complementarities in organizational design, building on the work of Topkis (1978), and we follow this approach.

In this paper we consider two related questions. First, to what extent does complementarity exist between cross-functional teamworking in different stages of the innovation process? In other words, does cross-functional teamworking in, say, prototyping contribute more to innovation outputs if there is also cross-functional working in later stages of a firm's innovation process? Secondly, we consider how complementarities in cross-functional teamworking are shaped by differences in UK and German firms' operating environments and internal capabilities. The UKGermany comparison is of particular interest both because of shortcomings in UK national innovation performance, differences in the nature of innovation activity in the two countries (e.g. Finegold and Wagner, 1998; Herrigel, 1996), and the marked institutional and organizational contrasts between the two countries (e.g. Finegold and Soskice, 1988; Dore et al., 1999; Culpepper, 1999; Love and Roper 2004).

The remainder of the paper is organized as follows. In Section 2 we briefly review the literature on cross-functional teams in the innovation process. Section 3 deals with the organization of production and innovation in UK and German firms, focussing particularly on factors shaping cross-functional working. Section 4 then describes our data and methodological approach which is based on recently developed tests

perceived as members by others (identity), and who collaborate on a common task (team-work)' Hoegl and Gemuenden, 2001, p. 436 
(Mohnen and Röller, 2005) for complementarity in situations where strategic decision variables are discrete (e.g. Topkis, 1998). That is, here, the decision to implement, or not implement, cross-functional teamworking in a particular element of the innovation process. Section 5 presents the key results and Section 6 discusses the implications.

\section{Cross-functional Teams and Innovation}

A number of studies have considered the use of cross-functional teams in the innovation process and their effect on innovation outputs. Zeller (2002), for example, describes the introduction of cross-functional teams as part of the restructuring of R\&D activities within pharmaceutical companies in response to the increasing globalisation of R\&D:“Implementing new organizational structures such as crossfunctional project teams, the pharmaceuticals pursued the goals of accelerating all relevant processes, in particular the development times, maintaining or improving innovative capabilities and integrating R\&D operations located at different places." (Zeller, 2002, p. 279). Zeller also stresses the importance of project teams in developing stronger interconnectedness between discovery, development and marketing activities and exploiting potential complementarities (see also, Bonnett, 1986; Gupta et al., 1986; Souder and Moenaert, 1992).

Positive empirical evidence also exists, however, relating the introduction of crossfunctional teams to firms' innovation outputs. Cooper and Kleinschmidt (1995), for example, identify firms' use of cross-functional teams as one of the key success factors determining the success of new product development projects, while Gupta and Wilemon (1996) emphasise the importance attached to the development of crossfunctional teams by R\&D and technology managers. Kusunoki et al. (1998) stress the importance of communication between groups and multi-functional teams has significant positive impact on innovativeness. The work of Aoki $(1986 ; 1990)$ indicates that lateral information flows between functional departments are a key factor in determining successful innovation, while other studies have emphasized the importance of informal knowledge flows (e.g. Allen, 1983). More recently, Michie and Sheehan (2003) consider firms with high levels of participation in team-work as part of their examination of the impact of alternative HRM systems on innovation. Their findings are positive in that the HRM systems which include cross-functional 
teams (their HRM1 and HRM2) have the strongest positive impact on innovation outputs. The HRM dimension is also considered by Lee and Chen (2007), who find that NPD project performance in Taiwan is positively linked both to crossfunctionality and to 'charged behaviour'

A particular focus in studies of cross-functional teams in innovation has been the integration of firms' R\&D and marketing functions, or in terms of Zeller (2002), integration of the discovery and development functions (Robertson and Langlois, 1995). Hise et al. (2002), for example, from their analysis of the new product development procedures of 252 large manufacturing companies, conclude that collaborative efforts between marketing and $R \& D$ are a key factor in explaining the success levels of new products. Similarly, in their review of evidence, Robertson and Langlois, 1995, p.553 conclude: "Independent of the degree of ownership integration, cross-functional and inter-firm project teams organizationally integrate parts of the production system in a selective way. This selective vertical integration contributes to speeding up innovation and development processes. The information flow and mutual understanding can be improved if researchers in discovery and development departments and even marketing people are unified at least temporarily in the same organization" (Robertson and Langlois, 1995, p. 553).

The strategic and organizational context within which cross-functional teams are implemented has also received significant attention in the literature. Zenger (2002) and others, for example, have argued that the range of effective organizational forms for innovation is not continuous but discrete, with choices defined by patterns of complementarity between system components. Conceptual support for this view can be found in the literatures on punctuated equilibrium models (e.g. Gersick, 1991; Tushman and Romanelli, 1985). Empirical evidence is also available, however, which emphasizes the complementarity between cross-functional teams and other HRM strategies (Laursen, 2002; Laursen and Foss, 2003; Michie and Sheehan, 2003) and elements of industrial organization (Lhuillery, 2000) ${ }^{6}$. One important implication is

\footnotetext{
${ }^{5}$ Defined as “... the drive, commitment, sense of joy and excitement, and members' behaviors." (Lee and Chen $(2007 ; 608)$

${ }^{6}$ Team performance may also depend, however, on leadership (e.g. Stoker et al, 2001), external threat or support (West, 2002) or teamwork quality (Hoegl and Gemuenden, 2001).
} 
that the potential impact on innovation of cross-functional teams may be lost if managers try to implement new systems in one part of the organization without understanding the complementarities involved elsewhere : "Such complementary pressures often unravel the bundle of elements that support traditional hierarchy and spiral hierarchies toward fundamental transformation. The clear trajectory of these transformations is toward quite radically, disaggregated organizations structured around teams. Complementary pressures, thus, push toward discrete organizational choices". (Zenger, 1997, p. 4).

The particular concern in the present paper is with the effects of using crossfunctional teams at different phases of the innovation process, which has received little empirical scrutiny. The benefits of cross-functional teams arise from synergies from different sets of views, skills, and expertise that can arise only through physical interaction of, and particularly verbal communication among, specialised personnel. While this will almost by definition improve communication within individual phases of the innovation process, the effect of using cross-functional teams across different stages of the process is less certain ${ }^{7}$.

Complementarity between cross-functional teams at different stages of the innovation process depends not only upon whether knowledge can be codified at one stage so that it can be transmitted to the next stage. Another, and perhaps more important, point is whether knowledge created at one stage can be properly understood at the next stage without the presence of specialists similar to those in the preceding stage. If maximum understanding of knowledge created at one stage requires the presence of specialists similar to those in the preceding stage, complementarity could arise in two ways: first, more of the knowledge created with the use of cross-functional teams at stage 1 might be properly understood by cross-functional teams at stage 2 , thus increasing productivity; and second, a greater use of cross-functional teams at stage 2 might allow team members to capitalise better on the knowledge created at stage 1 , thus increasing productivity.

\footnotetext{
${ }^{7}$ We are grateful to Hiro Izushi, Keld Laursen and an anonymous referee for detailed comments in developing the discussion in this section.
} 
However, this beneficial effect is not certain: under some circumstances the use of cross-functional team working may lead to negative (i.e. substitutability) effects when introducing the similar practice in another part of the firm. One reason is that cross-functional teamworking may enhance 'intra-functional stage' communication and knowledge sharing at the expense of 'cross-functional stage' communication and knowledge sharing. There is some suggestion in the empirical literature that this may occur, especially with regard to the involvement of the marketing function. In a study of 34 product development projects, Olson et al (2001) found that project performance for innovative products was higher where there was early-stage cooperation between $\mathrm{R} \& \mathrm{D}$ and marketing and between $\mathrm{R} \& \mathrm{D}$ and operations, but lower where there was early stage cooperation between marketing and operations. This suggests that the complementarity/substitutability of cross-functional teams in different stages of the innovation process is an empirical issue.

\section{Institutional and Contextual Framework}

Contrasts between the UK and German innovation system tend generally to focus on the nature of product change in the two countries as well as the social and industrial institutions. The German innovation and production system, for example, has been characterised as having a focus on diversified quality production (DQP), involving the incremental customisation of products rather than mass production or products derived from radical innovation (Streeck, 1989). "The resulting pattern of innovation is one that is more likely to generate improvements of existing products and sectors than to give rise to new sectors. Generally, sticky decisions, steady commitments and delayed responses in German institutions make for slow fluctuations, up or down, in economic activity and performance and for a low dispersion of outcomes" (Streeck, 1997, p. 41). By contrast, the UK innovation and production system has been characterised by its dependency on fickle capital markets, short-term business objectives and a more opportunistic (or entrepreneurial) approach to innovation (Roper, 1997; Dore et al., 1999). The consequence is a tendency towards more radical and sporadic innovation activity in the UK and a greater disparity in performance between leading edge and less well performing businesses (IBM/LBS, 1994). 
Both the UK and German innovation and production systems are strongly conditioned, however, by the wider social, legal and industrial relations systems within which they are set. Thus, DQP “is more than an individual firm's commercial strategy. It is conditional on an industrial order, or a social structure, that can only partly, provisionally and precariously exist on a voluntaristic-contractual basis. Where it is fully developed, it is the outcome of a collective 'cultural' choice mediated by and crystallised in a set of social institutions" (Streeck, 1992, p. 11). This will inevitably shape firms' ability to implement cross-functional teamworking. Herrigel (1996), for example, argues that the institutions which support DQP may be a barrier to the adoption by German firms of lean production concepts such as cross-functional teamworking. In particular, he suggests that the high degree of specialisation of German skilled workers and their 'culture' of disciplinary pride, coupled with the narrow functional orientation of managers from different disciplines, may make it more difficult for German firms to establish cross-functional teams or integrated product development teams. Finegold and Wagner (1998) found that while more than two-thirds of German pump manufacturers had adopted some form of teamworking and/or cellular manufacturing this tended to involve only a small proportion of all employees. Their evidence also suggested that German firms with more highly skilled workforces tended to find it more difficult to introduce multifunctional working because of potential loses in terms of job security and status by skilled individuals.

Offsetting these barriers to flexibility and cross-functional teams, Finegold and Wagner also suggest that: 'While the strong role that technical skills play in the identity of German skilled workers appears to be a significant barrier for some companies in the adoption of multifunctional teams ... supporting this transition to this new organization are: the strong general and applied skills that apprenticeships provide; the firm-based delivery of most training, Meisters' combination of comprehensive technical, economic/business and pedagogical skills ... and the already relatively broad span of control in most German plants' (Finegold and Wagner, 1998, p. 479).

In the UK, by contrast the weakness of the industrial training system may have the somewhat ironic advantage of avoiding some of the barriers to adopting innovative 
work practices evident in German firms. More concern here relates to the potentially negative role of unions and long-standing doubts about levels of basic and intermediate skills and the quality of UK manufacturing management (e.g. Handy, 1988).

These institutional differences have an identifiable effect on the organization of innovation in the two countries. Love and Roper (2004), for example, show that cross-functional teamworking is significantly more extensive among UK than German manufacturing plants. The nature of cross-functional teams in the two countries also differs, with more emphasis in the UK on the involvement of design staff, and more emphasis in Germany on the involvement of engineering staff. Overall, Love and Roper (2004) conclude that in Germany institutional and social norms and the narrow functional orientation of management hinders the adoption of flexible internal systems such as cross-functional teams, while in the UK a more market-oriented approach to innovation outcomes makes this form of flexibility easier to achieve.

\section{Data and Empirical Methodology}

The data we use here are taken from the Product Development Survey (PDS), a nationally representative postal survey of UK and German manufacturing plants' innovation activity (Roper et al., 1996; Love and Roper, 2004). In each country the sample was structured to allow size-band, regional and industry sector comparisons. Overall response rates were 20.6 per cent in the UK (1722 responses) and 25.1 per cent in Germany (1374 responses). The PDS relates to plants' innovation activity during the 1991 to 1993 period, at the beginning of the German recession of the mid1990s, and a time when the UK economy was also experiencing a mild recession (Roper et al., 1996, pp 8-9) ${ }^{8}$. The PDS is particularly well suited to examining complementarities between cross-functional teamworking because it provides detailed information both on firms' innovation outputs as well as the organization of firms' innovation activity (see, for example, Love and Roper, 2004).

\footnotetext{
${ }^{8}$ Fieldwork for this study pre-dates that reported in Finegold and Wagner (1998) by 18-24 months. The intervening period was one of continuing weakness in the German economy with total employment falling by 10 per cent between 1989 and 1995 (Finegold and Wagner, 1998, p. 473)
} 
Specifically, for innovating plants, the PDS reports the participation of staff from five major skill groups (i.e. scientists/technologists, engineers, designers, marketing and sales staff and skilled production workers) in four different elements of the product innovation process: identifying new products, product design and development, product engineering, product marketing ${ }^{9}$. This allows us to define four dichotomous strategy choice variables relating to firms' use of cross-functional teamworking in each of these elements of the product innovation process; cross-functional teamworking being said to exist where more than one skill group is involved in a specific element of the innovation process. Our key interest, however, is whether firms' choices in respect of cross-functional teamworking influence innovation output. To test this we use an innovation production function (e.g. Griliches, 1979; Love and Roper, 2001) which relates the percentage of sales derived from innovative products to a set of plant specific, industry and regional control variables along with the four strategy choice variables.

More formally, let $\mathrm{Z}=\left(\mathrm{z}_{1}, \ldots z_{i}, \ldots \mathrm{z}_{n}\right)$ be the vector of $n$ exogenous plant, industry and regional control variables, and $\mathrm{M}$ be the set of four dichotomous, strategy choice variables reflecting cross-functional teamworking in the different elements of the innovation process. Then the innovation production function can be written:

$$
I(M, Z)=f\left(m_{1}, m_{2}, m_{3}, m_{4}, z_{1}, \ldots z_{n}\right)
$$

To test for complementarities between the strategy choice variables - i.e. between cross-functional teamworking in the different elements of the innovation process - we use the framework proposed by Mohnen and Röller (2005). In this approach, the estimated form of the innovation production function is analysed directly to test for

\footnotetext{
${ }^{9}$ The PDS actually identifies the participation of each skill group in seven activities in the product innovation process. For some of these activities, however, the profile of cross-functional working was very similar (e.g. Love and Roper, 2004). For the current analysis, therefore, the original seven activities were grouped into four broader categories using cluster analysis. Specifically, 'prototyping' and 'final product development' were combined into 'product design and development'; 'product testing' and 'production engineering' were combined into 'product engineering'; and, 'market research' and 'sales strategy development' were grouped into 'product marketing'. The original activity 'identifying new products' was retained. Details of the cluster analysis are available from the authors.
} 
supermodularity or submodularity with respect to the four strategy choice variables $m_{j}{ }^{10}$

By way of illustration, consider a situation where there are only two strategy choice variables $m_{1}$ and $m_{2}$, such that the vectors (00), (01), (10) and (11) define all possible combinations of strategy options. Complementarity between the two strategy choices, or here the equivalent notion of supermodularity, in the innovation production function then requires that:

$I(10, Z)+I(01, Z) \leq I(00, Z)+I(11, Z)$

In other words, complementarity or supermodularity requires positive synergy between the two strategy choices, i.e. adopting both strategy choices together produces more positive effects on innovation outputs than the sum of the results produced by each strategy choice individually. Equivalently, equation (2) can be expressed as:

$I(10, Z)-I(00, Z) \leq I(11, Z)-I(01, Z)$.

In other words, complementarity or supermodularity requires that each strategy choice has a more positive effect on innovation outputs when the other strategy choice is also adopted.

With four strategy choice variables, such as those relating to cross-functional teamworking considered here, the situation is more complex with each pairing of strategy choices either exhibiting complementarity or substitutability. Supermodularity is then said to exist where there is complementarity between all possible pairings of strategy choices. Complementarity between the first two strategy choice variables requires that:

$$
I(10 X X, Z)+I(01 X X, Z) \leq I(00 X X, Z)+I(11 X X, Z)
$$

\footnotetext{
${ }^{10}$ Athey and Stern (1998) provide a detailed overview of this approach to assessing complementarity and a range of other possible approaches.
} 
where $X X=\{00,01,10,11\}$. This generates a set of four inequality constraints, one for each value of the set $X X .{ }^{11}$ For example, complementarity between crossfunctional teamworking in the first (identifying new products) and third (product engineering) elements of the innovation process requires that the following four inequalities hold:

$$
I(1 X 0 X, Z)+I(0 X 1 X, Z) \leq I(0 X 0 X, Z)+I(1 X 1 X, Z)
$$

The set of inequalities for the remaining combinations of strategy choice variables can be derived as an analogous procedure.

In operational terms, the key result is due to Topkis (1978), that pairwise complementarity over any subset implies supermodularity within that subset. This allows us to test for supermodularity for the set of four strategic choice variables using a set of six pairwise tests for complementarity, each independent pairwise test considering the validity of four simultaneous inequality constraints (e.g. equation (5)). Operationalising these hypothesis tests requires the inclusion in the innovation production function of mutually exclusive state dummies for the 16 possible combinations of the strategic choice variables. Conventionally, we label these state dummies (0000), (0001), .., (1111) following the rules of binary algebra. The state dummy labelled (0000), for example, indicates no cross-functional teamworking, while (0001) indicates cross-functional teamworking only in the fourth element of the product innovation process - product marketing. (1111) indicates cross-functional teamworking in each of the four elements of the innovation process.

The innovation production function we estimated can therefore be written as:

$$
I_{i}=\sum_{l=0}^{15} \gamma_{l} S_{l}+\beta Z_{i}+\varepsilon_{i}
$$

\footnotetext{
${ }^{11}$ Here we use the same notation as in Mohnen and Röller (2005).
} 
$I_{i}$ is innovation activity for firm $i$, measured as percentage of sales due to new products, a standard measure of innovation 'success'. The $s_{l}$ represent the set of 16 state variables, and $Z$ is the set of plant level, industry and regional controls. Although the elements of vector $Z$ are principally designed simply to control for plant-level heterogeneity, they are nevertheless variables which have previously been shown to be relevant determinants of innovative activity at the plant level (Love and Roper, 1999, 2001), including plant size, the intensity of internal (i.e. R\&D) and external knowledge sources, access to group resources, workforce qualifications, and the principal form of production in the plant. ${ }^{12}$ Descriptives and variable definitions are given in the Annex. Since the dependent variable measures the percentage of plants' sales due to innovative products, it can only take values between 0 and 100 . The nature of the dependent variable suggests that consistent estimates for the parameters of interest can be obtained by the estimation method proposed by Papke and Wooldridge (1996) for regression models with fractional response variables. ${ }^{13}$

\section{Empirical Results}

Table 1 reports the estimated innovation production functions for the UK and Germany using fractional response. In each case, observations are weighted to provide nationally representative results (see Roper et al., 1996), and both models include industry dummies (not reported). Wald tests of joint significance are reported for the state dummies, networking, size and other control variables. For both countries, the $\chi^{2}$ statistics suggest a high level of joint statistical significance for all sets of variables. Table 2 and 3 report the marginal effects for the state dummies and for the main control variables for each country. ${ }^{14}$

\footnotetext{
${ }^{12}$ In common with other cross-sectional studies of complementarities using the supermodularity approach (e.g. Mohnen and Röller, 2005; Galia and Legros, 2005) our limited ability to address fully the issues of endogeneity in organizational design must be acknowledged in interpreting the results of the analysis.

${ }^{13}$ See Wagner (2001) for a discussion of the econometric issues arising in the estimation of model with fractional response variable applied to the export/sales ratio.

${ }^{14}$ The estimated model includes a constant term, which is also retained in calculating the associated marginal effects. The omitted category for the state dummies is 0000 to allow comparison with the situation where no multifunctional teams are present. However, for the purpose of the complementarity test, the model is estimated without a constant as implied by Equation 6 .
} 
It must be borne in mind that the coefficients of the individual cross-functional team dummies do not by themselves provide any information on complementarity between different combinations of cross-functional teamworking. Testing for complementarity involves testing linear inequality restrictions, and indeed testing the joint distribution of several of these restrictions (Mohnen and Röller, 2005; Leiponen, 2005) ${ }^{15}$. Nevertheless, the individual dummies do give some indication of the effects of different combinations of cross-functional teamworking on innovation output. For the UK, the most positive combination of cross-functional teamworking, in terms of its effect on innovation outputs (see also Cooper and Kleinschmidt, 1995), is to use teamworking in product design and development and product marketing but not in identifying new products or production engineering (Table 1). Ceteris paribus, adopting this profile of cross-functional teamworking increases plants' percentage of innovative sales by 29.5 per cent compared to the reference group (i.e. those firms without cross-functional teams). For German plants, two patterns of cross-functional teamworking have significantly positive benefits in terms of innovation outputs. First, as in the UK, cross-functional teamworking in product design and development and product marketing but not in identifying new products or production engineering raises innovation output by 9.6 per cent (Table 2). Second, a weaker positive effect (a 5.0 per cent boost to innovative sales) is also obtained by German plants employing cross-functional teamworking in identifying new products, product design and development and production engineering. For German plants, however, there is also evidence that cross-functional teamworking in only the production engineering and product marketing elements of the innovation process may actually reduce innovative output by 11.3 per cent (Table 2 ).

As indicated earlier, assessing complementarity or substitutability between crossfunctional teamworking in different elements of the innovation process requires the joint testing of four inequality constraints for each pairwise comparison. Following Mohnen and Röller (2005), Table 3 reports the relevant Wald tests of the inequality restrictions (i.e. equation 5) based on the coefficient estimates on the state variables in the fractional response models (Table 1). In each pairwise comparison, separate tests

\footnotetext{
${ }^{15}$ For this reason the significance or otherwise of any or all of the individual dummies' coefficients is irrelevant in deciding whether the joint hypothesis of supermodularity is accepted or rejected.
} 
are required for the null hypotheses of complementarity and substitutability. Test values below the lower bound suggest that the null hypothesis of complementarity or substitutability cannot be rejected; values above the upper bound suggest rejection of the null; and, intermediate values suggest indeterminacy. Critical values at a 10 per cent significance level are 1.642 and 7.094 (see Kodde and Palm, 1986). For the UK, for example, the test for complementarity between identifying new products and product design and development is unable to reject the null hypothesis, while the test for substitutability is indeterminate. For this pairing the tests therefore suggest complementarity. Test results are summarised in symbolic form in Table 4 . In all but one case ${ }^{16}$ the test results give an unambiguous indication of either complementarity or substitutability, and in several cases acceptance of one is accompanied by rejection of the other (signified by an asterisk in Table 4).

Our test results suggest no clear evidence of either supermodularity or submodularity in cross-functional teamworking in either the UK or Germany (Table 4). That is, there is no universal pattern of complementarity or substituability between cross-functional teamworking in the product innovation process. Instead, in both countries, we see a more complex picture with potential synergies between cross-functional teamworking in different elements of the innovation process (Table 4). This provides some evidence in support of the general claims made by Cooper and Kleinschmidt (1995) and Robertson and Langlois (1995) for the positive role of cross-functional teamworking in innovation, but also suggests a need for a more focussed strategic approach taking into account specific patterns of complementarity.

In the UK, for example, Tables 3 and 4 indicate that there is complementarity between the first and second, second and third, and first and third elements of the innovation process, which in turn indicates joint complementarity between all three elements. There is therefore clear evidence of separability between the product marketing element of the innovation process and the other three elements of the process (i.e. identifying new products, product engineering and production engineering). In other words, positive synergies between cross-functional teamworking are limited to identifying new products, product engineering and production engineering, and the

\footnotetext{
${ }^{16}$ This case is product design and development and product marketing in the UK, where both test statistics are in the indeterminate region (Table 3 ).
} 
benefits of cross-functional teamworking in each of these elements of the process is reduced if a plant also has cross-functional teamworking in product marketing. This conflicts with earlier studies which have emphasised the importance of crossfunctional teamworking, particularly in marketing (Zeller, 2002; Hise et al., 2002). Instead, our results suggest that synergies from cross-functional teamworking are likely to be strongest in the more technical or engineering elements of the innovation process. One possibility is that these elements of the innovation process may have more internal commonality in either their organizational requirements, or approach to knowledge management, than they have with marketing. Similarities in terms of organizational or management structures, for example, may allow firms to exploit economies of scope in the management of cross-functional teamworking in these elements of the innovation process. Or, similarities in terms of their approaches to knowledge codification (e.g. product specifications, designs etc.) may enable synergies between product identification, design and development to be more easily exploited via cross-functional teams than those with marketing.

At first sight, the results for Germany appear similar to those for the UK (Table 4 part B). For example, cross-functional teamworking in production engineering exhibits synergy with that in identifying new products and in product design and development, while cross-functional teamworking in product marketing has a less positive relationship with that in most other stages of the product innovation process. There are, however, distinct differences from the British case which highlight variations in the organization of innovation. In particular, the first (identification) stage of the process exhibits strong substitutability with the product design and development stage i.e. the benefits of cross-functional teamworking in product identification is reduced if a plant also has cross-functional teamworking in the product design and development stage. In addition, there is evidence of a complementary relationship between crossfunctional teamworking in product design and marketing, the only case in which marketing exhibits such a relationship. This much more patchy picture of complementarity in cross-functional teamworking in Germany appears to support the contention that implementation issues for cross-functional teamworking in Germany due to high levels of specialisation more than outweigh any positive effect due to higher average skill levels vis-à-vis the UK (Herrigel, 1996; Finegold and Wagner, 1998; Love and Roper, 2004) 


\section{Conclusions}

Cross-functional teamworking has been strongly advocated as part of leading practice innovation strategy, with attention focussed largely on team organization, management and psychology (e.g. von Stamm, 2003, pp. 125-138). Our focus here has been to assess the benefits of cross-functional teamworking for innovation, and specifically to test for complementarities between cross-functional teamworking in different elements of the innovation process. To our knowledge, this has never been studied before.

In terms of the benefits of cross-functional teamworking we find some evidence, both in the UK and Germany, suggesting synergies in the implementation of crossfunctional teamworking, notably in product design and development and product engineering. Other combinations of cross-functional teamworking prove less positive for innovation, suggesting that cross-functional teamworking is not a universal good, and implemented wrongly can actually have a negative impact on innovation output. Moreover, we also find no evidence for supermodularity in relation to crossfunctional teamworking in our innovation production functions for either the UK or Germany. In other words, complementarity between cross-functional teamworking in different elements of the innovation process cannot be assumed. Instead, in some activities, most notably marketing, cross-functional teamworking may have a negative effect on the benefits of cross-functional teamworking implemented elsewhere.

Our evidence suggests some broad similarities, but also some key differences, between the UK and Germany in terms of the optimal combination of innovation activities in which to implement cross-functional teamworking, and in terms of the substitution effect of cross-functional teamworking in marketing and other elements of the innovation process. In general terms, however, synergies between crossfunctional teamworking in different elements of the innovation process, while not necessarily more common, are more systematic in the UK. This provides some support for the contention of Herrigel (1996) and Fingold and Wagner (1998) that 
occupational specialisation in German firms may reduce their ability to introduce effectively cross-functional teams.

In an earlier study (Love and Roper, 2004), we showed that at the national level crossfunctional teamworking was more common in the UK than in Germany in almost all elements of the innovation process, and argued that this reflected broader institutional factors. Given these marked differences, it my seem initially surprising that the degree of complementarity in cross-functional teamworking in the UK is not markedly greater in the UK than in Germany: as indicated above, the pattern is different and somewhat more systematic in the UK, but there is no more evidence of supermodularity in cross-functional teamworking in the UK than in Germany. However, this would be to confuse the extent of cross-function teamworking with its effectiveness when used in combination. Our results here suggest some important commonalities between the organizational effects of cross-functional teamworking in UK and German plants which transcend the institutional differences between the two countries. In particular, our analysis suggests that cross-functional teamworking has a substantial positive impact on innovation outputs in both countries, and that in both countries synergies are strongest between cross-functional teamworking in the more technical elements of the innovation process. Little synergy is evident in either country between cross-functional teamworking in the development of market strategy and teamworking elsewhere in the innovation process. This may suggest that the trade-off between 'intra-functional stage' communication and 'cross-functional stage' communication and knowledge sharing alluded to in Section 2 is particularly acute at the marketing stage of the innovation process

These commonalities suggest some strategic lessons and links with the previous literature in the area. Like other studies our results suggest the potential importance of cross-functional teamworking for firms seeking to increase their innovation outputs. In this respect our findings accord with Cooper and Kleinschmidt (1995), Gupta and Wilemon (1996) and Kusunoki et al. (1998), all of which stress the importance of cross-functional teamworking in new product development. However, our findings go beyond the current literature in terms of examining complementarities in teamworking in different stages of the innovation process. Our results suggest the importance of implementing cross-functional teams in the appropriate elements of the 
innovation process to maximise potential complementarities; implementing team working in the 'wrong' elements of the innovation process can have a negative effect on innovation output. In particular, our results suggest the potential value of crossfunctional team working in the more technical aspects of the innovation process, but that the development of market strategy should remain a focussed, single discipline activity. This finding casts doubt on the literature which advocates the importance of project teams in developing stronger interconnectedness and complementarities between the discovery, development and marketing activities (Zeller, 2002; Gupta et al., 1986; Souder and Moenaert, 1992). Our results do, however, offer support for the hypothesis of Zenger (1997) that complementary pressures push toward discrete organizational choices, and that the potential impact on innovation of cross-functional teams may be lost if managers try to implement new systems in one part of the organization without understanding the complementarities involved elsewhere. 
Table 1: Innovative Products as a Percentage of Sales - Fractional response model

\begin{tabular}{|c|c|c|}
\hline & United Kingdom & Germany \\
\hline \multirow[t]{2}{*}{ Wald test of overall significance } & $\operatorname{chi} 2(34)=121.35$ & $\operatorname{chi} 2(35)=847.85$ \\
\hline & $(0.0000)$ & $(0.0000)$ \\
\hline 0001 & $\begin{array}{r}0.96704 \\
(0.213)\end{array}$ & $\begin{array}{r}0.16471 \\
(0.453)\end{array}$ \\
\hline 0010 & $\begin{array}{r}-0.36560 \\
(0.474) \\
\end{array}$ & $\begin{array}{r}-0.33990 \\
(0.434) \\
\end{array}$ \\
\hline 0011 & $\begin{array}{r}0.15502 \\
(0.723)\end{array}$ & $\begin{array}{r}-1.28404 \\
(0.000)^{* * *}\end{array}$ \\
\hline 0100 & $\begin{array}{r}-0.07240 \\
(0.843)\end{array}$ & $\begin{array}{r}-0.09638 \\
(0.635)\end{array}$ \\
\hline 0101 & $\begin{array}{r}1.35969 \\
(0.005) * * * \\
\end{array}$ & $\begin{array}{r}0.58152 \\
(0.008)^{* * *} \\
\end{array}$ \\
\hline 0110 & $\begin{array}{r}-0.21060 \\
(0.520)\end{array}$ & $\begin{array}{r}0.31847 \\
(0.314)\end{array}$ \\
\hline 0111 & $\begin{array}{r}0.46876 \\
(0.205) \\
\end{array}$ & $\begin{array}{r}0.10237 \\
(0.681) \\
\end{array}$ \\
\hline 1000 & $\begin{array}{r}-0.17227 \\
(0.761) \\
\end{array}$ & $\begin{array}{r}0.35571 \\
(0.307) \\
\end{array}$ \\
\hline 1001 & $\begin{array}{r}0.69141 \\
(0.102)\end{array}$ & $\begin{array}{r}-0.00785 \\
(0.974)\end{array}$ \\
\hline 1010 & $\begin{array}{r}0.04796 \\
(0.900)\end{array}$ & $\begin{array}{r}0.55048 \\
(0.186)\end{array}$ \\
\hline 1011 & $\begin{array}{r}-0.64673 \\
(0.256) \\
\end{array}$ & $\begin{array}{r}0.25465 \\
(0.414) \\
\end{array}$ \\
\hline 1100 & $\begin{array}{r}0.65584 \\
(0.080)^{*}\end{array}$ & $\begin{array}{r}0.35245 \\
(0.155) \\
\end{array}$ \\
\hline 1101 & $\begin{array}{r}0.48538 \\
(0.171)\end{array}$ & $\begin{array}{r}0.19662 \\
(0.459) \\
\end{array}$ \\
\hline 1110 & $\begin{array}{r}0.18503 \\
(0.552)\end{array}$ & $\begin{array}{r}0.32977 \\
(0.025)^{* *}\end{array}$ \\
\hline 1111 & $\begin{array}{r}0.25740 \\
(0.397) \\
\end{array}$ & $\begin{array}{r}0.28156 \\
(0.156) \\
\end{array}$ \\
\hline $\begin{array}{l}\text { All state dummies }(0001-1111) \\
\text { (Wald test) }\end{array}$ & $\begin{array}{r}\operatorname{chi} 2(15)=35.88 \\
(0.0018)\end{array}$ & $\begin{array}{r}\operatorname{chi} 2(15)=69.82 \\
(0.0000)\end{array}$ \\
\hline R\&D intensity & $\begin{array}{r}0.00854 \\
(0.480) \\
\end{array}$ & $\begin{array}{r}0.01071 \\
(0.035)^{* *} \\
\end{array}$ \\
\hline Technology transfer intensity & $\begin{array}{r}-0.00129 \\
(0.694) \\
\end{array}$ & $\begin{array}{r}0.00553 \\
(0.146) \\
\end{array}$ \\
\hline Networking intensity & $\begin{array}{r}0.00095 \\
(0.741)\end{array}$ & $\begin{array}{r}0.01138 \\
(0.008)^{* * *} \\
\end{array}$ \\
\hline $\begin{array}{l}\text { R\&D technology transfer and } \\
\text { networking intensity (Wald test) }\end{array}$ & $\begin{array}{r}\operatorname{chi} 2(3)=0.82 \\
(0.8451) \\
\end{array}$ & $\begin{array}{r}\operatorname{chi} 2(3)=13.13 \\
(0.0044) \\
\end{array}$ \\
\hline Employment (Thousands) & $\begin{array}{r}0.18531 \\
(0.437)\end{array}$ & $\begin{array}{r}0.28059 \\
(0.114)\end{array}$ \\
\hline Employment squared & $\begin{array}{r}-0.01950 \\
(0.223) \\
\end{array}$ & $\begin{array}{r}-0.01584 \\
(0.625) \\
\end{array}$ \\
\hline $\begin{array}{l}\text { Employment and Employment } \\
\text { squared (Wald test) }\end{array}$ & $\begin{array}{r}\operatorname{chi} 2(2)=5.79 \\
(0.0554)\end{array}$ & $\begin{array}{r}\operatorname{chi} 2(2)=13.86 \\
(0.0010)\end{array}$ \\
\hline Part of group & $\begin{array}{r}-0.15615 \\
(0.245) \\
\end{array}$ & $\begin{array}{r}-0.37380 \\
(0.010)^{* * *}\end{array}$ \\
\hline External ownership dummy & $\begin{array}{r}0.03371 \\
(0.845) \\
\end{array}$ & $\begin{array}{r}0.29192 \\
(0.441)\end{array}$ \\
\hline $\begin{array}{l}\text { Part of group and external ownership } \\
\text { (Wald test) }\end{array}$ & $\begin{array}{r}\operatorname{chi} 2(2)=1.36 \\
(0.5076) \\
\end{array}$ & $\begin{array}{r}\operatorname{chi} 2(2)=6.82 \\
(0.0330) \\
\end{array}$ \\
\hline Workforce with degree & $\begin{array}{r}0.00224 \\
(0.747)\end{array}$ & $\begin{array}{r}0.01310 \\
(0.040)^{* *}\end{array}$ \\
\hline Workforce with no qualifications & $\begin{array}{r}-0.00178 \\
(0.498)\end{array}$ & $\begin{array}{r}0.00049 \\
(0.848)\end{array}$ \\
\hline $\begin{array}{l}\text { Workforce with degree and no qualifications } \\
\text { (Wald test) }\end{array}$ & $\begin{array}{r}\operatorname{chi} 2(2)=0.71 \\
(0.7016)\end{array}$ & $\begin{array}{r}\operatorname{chi} 2(2)=4.58 \\
(0.1014)\end{array}$ \\
\hline Small batch production & $\begin{array}{r}-0.19631 \\
(0.169)\end{array}$ & $\begin{array}{r}0.13775 \\
(0.243)\end{array}$ \\
\hline Large batch production & $\begin{array}{r}-0.10010 \\
(0.431) \\
\end{array}$ & $\begin{array}{r}0.03367 \\
(0.822) \\
\end{array}$ \\
\hline One-off production & $\begin{array}{r}-0.28696 \\
(0.087)^{*}\end{array}$ & $\begin{array}{r}-0.27684 \\
(0.065)^{*}\end{array}$ \\
\hline Continuous production & $\begin{array}{r}0.02635 \\
(0.872)\end{array}$ & $\begin{array}{r}0.17993 \\
(0.254)\end{array}$ \\
\hline All production types & $\operatorname{chi} 2(4)=7.16$ & $\operatorname{chi} 2(4)=7.73$ \\
\hline
\end{tabular}




\begin{tabular}{|l|r|r|}
\hline (Wald test) & 0.1275 & 0.1020 \\
\hline Former DDR & NA & 1.17748 \\
& & $(0.000)^{* * *}$ \\
\hline Constant & -1.40838 & -2.57356 \\
& $(0.001)^{* * *}$ & $(0.000)^{* * *}$ \\
\hline Observations & 531 & 449 \\
\hline
\end{tabular}

Notes: Observations are weighted to give representative results and models include industry dummy variables. Robust $\mathrm{p}$ values in parentheses * significant at $10 \%$; ** significant at $5 \%$; *** significant at $1 \%$ 
Table 2: Marginal effects from Fractional Response Models

\begin{tabular}{|c|c|c|c|c|c|c|}
\hline \multirow[b]{2}{*}{ Variable } & \multicolumn{3}{|c|}{ UK } & \multicolumn{3}{|c|}{ Germany } \\
\hline & $\mathrm{dy} / \mathrm{dx}$ & Std. Err. & $\mathrm{z}$ & $\mathrm{dy} / \mathrm{dx}$ & Std. Err. & $\mathrm{z}$ \\
\hline 0001* & 0.198 & 0.179 & 1.11 & 0.024 & 0.033 & 0.73 \\
\hline $0010^{*}$ & -0.053 & 0.072 & -0.74 & -0.042 & 0.048 & -0.87 \\
\hline 0011* & 0.026 & 0.075 & 0.35 & -0.113 & 0.018 & -6.25 \\
\hline $0100^{*}$ & -0.011 & 0.058 & -0.2 & -0.013 & 0.027 & -0.48 \\
\hline $0101 *$ & 0.295 & 0.106 & 2.79 & 0.096 & 0.039 & 2.45 \\
\hline 0110* & -0.032 & 0.052 & -0.62 & 0.049 & 0.052 & 0.93 \\
\hline 0111* & 0.086 & 0.068 & 1.28 & 0.015 & 0.036 & 0.4 \\
\hline $1000^{*}$ & -0.026 & 0.085 & -0.31 & 0.055 & 0.059 & 0.93 \\
\hline $1001^{*}$ & 0.134 & 0.083 & 1.61 & -0.001 & 0.032 & -0.03 \\
\hline $1010^{*}$ & 0.008 & 0.063 & 0.13 & 0.090 & 0.077 & 1.16 \\
\hline $1011^{*}$ & -0.085 & 0.070 & -1.22 & 0.038 & 0.049 & 0.77 \\
\hline $1100^{*}$ & 0.126 & 0.070 & 1.79 & 0.054 & 0.041 & 1.33 \\
\hline $1101 *$ & 0.090 & 0.064 & 1.41 & 0.029 & 0.041 & 0.71 \\
\hline $1110^{*}$ & 0.032 & 0.051 & 0.62 & 0.050 & 0.022 & 2.26 \\
\hline $1111^{*}$ & 0.045 & 0.050 & 0.9 & 0.042 & 0.031 & 1.36 \\
\hline$R \& D$ intensity & 0.002 & 0.002 & 0.71 & 0.002 & 0.001 & 2.11 \\
\hline Technology transfer intensity & 0.000 & 0.001 & -0.39 & 0.001 & 0.001 & 1.45 \\
\hline Networking intensity & 0.000 & 0.001 & 0.33 & 0.002 & 0.001 & 2.62 \\
\hline Employment (Thousands) & 0.033 & 0.043 & 0.78 & 0.043 & 0.027 & 1.58 \\
\hline Employment squared & -0.004 & 0.003 & -1.22 & -0.002 & 0.005 & -0.49 \\
\hline Part of group* & -0.028 & 0.024 & -1.16 & -0.053 & 0.019 & -2.76 \\
\hline External ownership* & 0.006 & 0.031 & 0.19 & 0.049 & 0.069 & 0.71 \\
\hline Workforce with degree & 0.000 & 0.001 & 0.32 & 0.002 & 0.001 & 2.08 \\
\hline Workforce with no qualifications & 0.000 & 0.000 & -0.68 & 0.000 & 0.000 & 0.19 \\
\hline Small batch production* & -0.036 & 0.026 & -1.36 & 0.021 & 0.018 & 1.16 \\
\hline Large batch production* & -0.018 & 0.023 & -0.79 & 0.005 & 0.023 & 0.22 \\
\hline One-off production* & -0.049 & 0.028 & -1.79 & -0.041 & 0.021 & -1.91 \\
\hline Continuous production* & 0.005 & 0.030 & 0.16 & 0.028 & 0.026 & 1.11 \\
\hline Former DDR & & & & 0.232 & 0.033 & 7.11 \\
\hline
\end{tabular}

Notes: * denotes marginal effect is for discrete change of dummy variable from 0 to 1 .

Marginal effects for each state dummy are calculated setting all other state dummies at zero and all other variables at their mean values. Marginal effects for variables other than state dummies are calculated setting all variables at their mean value. 
Table 3: Wald Test Results for Complementarity and Substitutability Between Cross-Functional Teamworking

\begin{tabular}{|c|c|c|c|c|c|c|}
\hline & $\begin{array}{l}\text { Identifying } \\
\text { new products } \\
\text { Product design } \\
\text { and } \\
\text { development }\end{array}$ & $\begin{array}{l}\text { Identifying } \\
\text { new } \\
\text { Products } \\
\text { Product } \\
\text { Engineering }\end{array}$ & $\begin{array}{l}\text { Identifying } \\
\text { new products } \\
\text { Product } \\
\text { Marketing }\end{array}$ & $\begin{array}{l}\text { Product design } \\
\text { and } \\
\text { development } \\
\text { Product } \\
\text { Engineering }\end{array}$ & $\begin{array}{l}\text { Product design } \\
\text { and } \\
\text { development } \\
\text { Product } \\
\text { Marketing }\end{array}$ & $\begin{array}{l}\text { Product } \\
\text { Engineering } \\
\text { Product } \\
\text { Marketing }\end{array}$ \\
\hline A. UK & & & & & & \\
\hline Complementarity & 0.454 & 0.942 & 15.847 & 1.354 & 2.350 & 5.846 \\
\hline Substitutability & 2.694 & 2.330 & 0.000 & 3.240 & 2.268 & 0.464 \\
\hline B. Germany & & & & & & \\
\hline Complementarity & 10.273 & 0.979 & 5.049 & 0.303 & 0.000 & 6.982 \\
\hline Substitutability & 0.045 & 15.623 & 1.145 & 7.034 & 5.058 & 0.092 \\
\hline
\end{tabular}

Notes: See text for derivation. Wald test of inequality restrictions based on fractional response model. Critical values for $\alpha=0.10$ are 1.642 for lower bound and 7.094 for upper bound. If the Wald statistic is below the lower bound, the null hypothesis of complementarity or substitutability cannot be rejected. If the Wald statistic is above the upper bound, the null hypothesis is rejected. The test is inconclusive for intermediate values. 
Table 4: Summary of Patterns of Complementarity and Substitutability in Cross-Functional Teamworking in the UK and Germany

\begin{tabular}{|l|c|c|c|}
\hline & $\begin{array}{c}\text { Identifying } \\
\text { new products }\end{array}$ & $\begin{array}{c}\text { Product design } \\
\text { and } \\
\text { development }\end{array}$ & $\begin{array}{c}\text { Product } \\
\text { engineering }\end{array}$ \\
\hline A. UK & & & \\
\hline Identifying new products & & & \\
\hline Product design and development & $\mathrm{C}$ & $\mathrm{C}$ & \\
\hline Product engineering & $\mathrm{C}$ & $\mathrm{I}$ & $\mathrm{S}$ \\
\hline Product marketing & $\mathrm{S}^{*}$ & & \\
\hline & & & \\
\hline B. Germany & & & \\
\hline Identifying new products & & & \\
\hline Product design and development & $\mathrm{S}^{*}$ & $\mathrm{C}$ & $\mathrm{S}$ \\
\hline Product engineering & $\mathrm{C}^{*}$ & $\mathrm{C}$ & \\
\hline Product marketing & $\mathrm{S}$ & $\mathrm{C}$ & \\
\hline
\end{tabular}

Notes: $\mathrm{C}$ denotes complementarity; $\mathrm{S}$ denotes substitutability; I denotes test inconclusive at $10 \%$ level. * denotes that failure to reject the null is also accompanied by rejection of the alternative 


\begin{tabular}{|c|c|c|}
\hline Variable & $\begin{array}{r}\text { UK } \\
\text { Mean } \\
\text { (Std. Dev) } \\
\end{array}$ & $\begin{array}{r}\text { Germany } \\
\text { Mean } \\
\text { (Std. Dev) } \\
\end{array}$ \\
\hline $\begin{array}{l}\text { R\&D intensity of the plant - percentage of the } \\
\text { workforce engaged in R\&D activity ( } \% \text { of } \\
\text { employment) }\end{array}$ & $\begin{array}{r}4.091 \\
(5.678)\end{array}$ & $\begin{array}{r}4.524 \\
(6.480)\end{array}$ \\
\hline $\begin{array}{l}\text { Technology transfer intensity - level variable } \\
\text { indicating plants' use of potential within-group } \\
\text { linkages }(\%)^{2}\end{array}$ & $\begin{array}{r}8.915 \\
(19.440)\end{array}$ & $\begin{array}{r}2.711 \\
(10.347)\end{array}$ \\
\hline $\begin{array}{l}\text { Networking intensity - level variable indicating } \\
\text { plants' use of potential extra-group linkages }(\%)^{2}\end{array}$ & $\begin{array}{r}11.830 \\
(18.020)\end{array}$ & $\begin{array}{r}12.287 \\
(11.970)\end{array}$ \\
\hline Plant employment (thousands) & $\begin{array}{r}0.133 \\
(0.302)\end{array}$ & $\begin{array}{r}0.245 \\
(0.489)\end{array}$ \\
\hline Plant is member of multi-plant group ${ }^{3}$ & $\begin{array}{r}0.521 \\
(0.500)\end{array}$ & $\begin{array}{r}0.156 \\
(0.363)\end{array}$ \\
\hline Plant is foreign-owned ${ }^{3}$ & $\begin{array}{r}0.152 \\
(0.359)\end{array}$ & $\begin{array}{r}0.023 \\
(0.149)\end{array}$ \\
\hline $\begin{array}{l}\text { Percentage of the workforce with degree level } \\
\text { qualification ( } \% \text { of employment) }\end{array}$ & $\begin{array}{r}7.545 \\
(9.178)\end{array}$ & $\begin{array}{r}6.971 \\
(6.945)\end{array}$ \\
\hline $\begin{array}{l}\text { Percentage of the workforce with no post-school } \\
\text { qualifications ( } \% \text { of employment) }\end{array}$ & $\begin{array}{r}49.373 \\
(28.542)\end{array}$ & $\begin{array}{r}34.092 \\
(26.260)\end{array}$ \\
\hline $\begin{array}{l}\text { Plant is predominantly engaged in the production of } \\
\text { small batches }{ }^{3}\end{array}$ & $\begin{array}{r}0.544 \\
(0.499)\end{array}$ & $\begin{array}{r}0.485 \\
(0.500)\end{array}$ \\
\hline $\begin{array}{l}\text { Plant is predominantly engaged in the production of } \\
\text { large batches }{ }^{3}\end{array}$ & $\begin{array}{r}0.304 \\
(0.460)\end{array}$ & $\begin{array}{r}0.212 \\
(0.409)\end{array}$ \\
\hline $\begin{array}{l}\text { Plant is predominantly engaged in one-off } \\
\text { production }^{3}\end{array}$ & $\begin{array}{r}0.207 \\
(0.405)\end{array}$ & $\begin{array}{r}0.249 \\
(0.433)\end{array}$ \\
\hline $\begin{array}{l}\text { Plant is predominantly engaged continuous } \\
\text { production }\end{array}$ & $\begin{array}{r}0.211 \\
(0.410)\end{array}$ & $\begin{array}{r}0.297 \\
(0.457)\end{array}$ \\
\hline Plant is located in former $\mathrm{DDR}^{3}$ & & $\begin{array}{r}0.097 \\
(0.296)\end{array}$ \\
\hline
\end{tabular}

\section{Notes}

1. Sample observations were weighted to allow for sample structuring. 
2. Definitions of technology transfer intensity and networking intensity follow Love and Roper (2001) and indicate plants' links to other group plants and unrelated plants as part of their innovation activities. Specifically, as part of the PDS plants were asked whether they had links to other group plants and unrelated plants in seven different elements of the innovation process. Intensity scores for each form of interaction were then derived based on these responses, i.e. plants reporting links in all seven elements of the innovation process scored 100, whereas those reporting no linkages scored 0.

3. Denotes dummy variable. 


\section{References}

Allen, R. C. (1983), 'Collective invention', Journal of Economic Behaviour and Organization, 4, 1-24.

Aoki, M. (1986) 'Horizontal vs. Vertical Information Structures of the Firm', American Economic Review, 76, 971-983.

Aoki, M.(1990) 'Toward an economic model of the Japanese firm', Journal of Economic Literature, 28, 1-27.

Athey, S and Stern, S (1998) An Empirical Framework for Testing Theories About Complementarity in Organizational Design. NBER Working Paper 6600.

Bonnett, D. (1986) 'Nature of the R\&D/marketing co-operation in the design of technologically advanced new industrial products', $R \& D$ Management, $6,117-26$

Cassiman, B and Veugelers, R (2002) 'Complementarity in Innovation Strategy: Internal R\&D, External Technology Acquisition and Cooperation in R\&D’, paper presented at EARIE, Madrid, August.

Cooper, R G Kleinschmidt. E. J. (1995). Benchmarking for firm's critical success factors in new product development. Journal of Product Innovation Management, 12 374- 391 .

Creed D. W. E. and Miles R. E. (1996) 'Trust in organizations: a conceptual framework linking organizational forms, managerial philosophies, and the opportunity costs of controls', in Kramer, R M and Tyler, T R (Eds) Trust in Organizations: Frontiers of Theory and Research, pp. 16-38. Sage, Thousand Oaks, CA/London/New Delhi.

Dore, R., Lazonick, W. and O'Sullivan, M. (1999). Varieties of capitalism in the twentieth century, Oxford Review of Economic Policy, vol 15, 102-120

Culpepper, P. D. (1999), 'The future of the high-skill equilibrium in Germany', Oxford Review of Economic Policy, 15, 43-59.

Finegold, D. and Soskice, D. (1988) 'The failure of training in Britain: analysis and prescription', Oxford Review of Economic Policy, 4, 21-53.

Finegold, D. and Wagner, K. (1998) 'The search for flexibility: skills and workplace innovation in the German pump industry', British Journal of Industrial Relations, 36, 469-487.

Galia, F and Legros, D (2005) 'Testing for complementarities between team incentives, training and knowledge management: evidence from France', paper presented at workshop on Organizing the Search for Technological Innovation, Copenhagen Business School, October. 
Gersick, C. J.G. (1991), 'Revolutionary Change Theories: A multi-level explanation of the punctuated equilibrium paradigm', Academy of Management Review, 16, 30-36.

Grabher, G (2001) Locating economic action: projects, networks, localities, institutions, introductory notes for the workshop, Beyond the Firm? Spatial and Social Dynamics of Project-Organization, Bonn, April.

Griliches, Z. 1979. "Issues in Assessing the Contribution of Research and Development to Productivity Growth.” Bell Journal of Economics 10, 1, 92-116.

Gupta, A K and Wilemon, D (1996) 'Changing patterns in industrial R\&D management', Journal of Product Innovation Management, 13, 497- 511.

Gupta, A. K., S. P. Raj, and D. Wilemon. (1987) 'Managing the R\&D-marketing interface', Research Management, 30, 38-43.

Handy, C. (1988) Making Managers, London, Pitman

Herrigel, G. (1996) Crisis in German decentralised production, European Urban and Regional Studies, 33-52

IBM and LBS (1994) Made in Europe: a Four Nations Best Practice Study, London.

Hise, R. T., L. O’Neal, A. Parasuraman, J. U. McNeal (1990) 'Marketing R\&D interaction in new product development: Implications for new product success', Journal of Product Innovation Management, 7,142- 155.

Hoegl, M, and Gemuenden, HG (2001) 'Teamwork quality and the success of innovative projects: a theoretical concept and empirical evidence', Organization Science, 12, 435-449.

Keck, O. 1993. 'The national system for technical innovation in Germany', in Nelson, R. (ed), National Innovation Systems, Oxford, Oxford University Press.

Kodde, D A. and Palm, F C (1986) 'Wald Criteria for Jointly Testing Equality and Inequality Restrictions', Econometrica, 54, 1243-1248.

Kusunoki K., Nonaka I., and Nagata A., (1998) 'Organizational Capabilities in Product Development of Japanese Firms: A Conceptual Framework and Empirical Findings', Organization Science, 9, 699-718.

Labeaga, J M and Martinez Ros E (2003) 'Persistence and ability in the innovation decisions', Working Paper 03-01, University Carlos III de Madrid.

Laursen, K (2002) 'The importance of sectoral differences in the application of complementary HRM practices for innovation performance' International Journal of the Economics of Business, 9, 139-156. 
Laursen, K and Foss, N J (2003) 'New human resource management practices, complementarities and the impact on innovation performance', Cambridge Journal of Economics, 27, 243-263.

Lee C and Chen W-J (2007) 'Cross-functionality and charged behaviour of the new product development teams in Taiwan's information technology industries', Technovation, 27, 605-615.

Leiponen, A (2005) 'Skills and innovation', International Journal of Industrial Organization, 23, 303-323.

Levine, D. (1995) 'Re-inventing the Workplace’, Washington, Brookings Institute

Lhuillery, S (2000) "The Organizational Practices of Innovation and the Performances of Firms: An Empirical Investigation", DYNACOM Working Paper.

Love, J. H. and Roper, S. (1999) 'The determinants of innovation: R\&D, technology transfer and networking effects', Review of Industrial Organization, 15, 43-64.

Love, J. H. and Roper, S (2001) 'Location and network effects on innovation success: evidence for UK, German and Irish manufacturing plants', Research Policy, 30, 64361 .

Love J H and Roper S (2002) 'Internal versus external R\&D: a study of R\&D choice with sample selection, International Journal of the Economics of Business, 9, 239-255.

Love, J H and Roper, S (2004) 'The Organisation of Innovation: Collaboration, Cooperation and Multifunctional Groups in UK and German Manufacturing', Cambridge Journal of Economics, 28, 379-395.

Michie, J and Sheehan, M (2003) 'Labour market deregulation, 'flexibility' and innovation', Cambridge Journal of Economics, 27, 123-143.

Milgrom, P and Roberts, J. (1990) "The economics of modern manufacturing: technology, strategy, and organization." American Economic Review, 80, 511-528.

Milgrom, P and Roberts, J (1995)'Complementarities and fit: strategy, structure, and organizational change in manufacturing', Journal of Accounting and Economics, 19, 179-208.

Mohnen, P and Röller, L-H (2005) 'Complementarities in Innovation Policy', European Economic Review, 49, 1431-1450.

Olson E M, Walker O C, Ruekerf R W and Bonnerd J M (2001) 'Patterns of cooperation during new product development among marketing, operations and R\&D: implications for project performance', Journal of Product Innovation Management, $18,258-271$. 
Papke, L E. and J M. Wooldridge (1996) 'Econometric Methods for Fractional Response Variables with an Application to 401 (K) Plan Participation Rates',. Journal of Applied Econometrics, 11, 619-632.

Porter, M (1996) 'What is Strategy? 'Harvard Business Review, 74(6), 61-78.

Quah, D (2001) 'The Weightless Economy in Economic Development' in Information Technology, Productivity and Economic Growth: International Evidence and Implications for Economic Development, M. Pohjola (ed.), Oxford University Press, Oxford.

Robertson P. L. and Langlois, R. N. (1995) 'Innovation, networks, and vertical integration', Research Policy 24, 543- 62.

Roper, S. (1997) 'Product innovation and small business growth: a comparison of the strategies of German, UK and Irish companies', Small Business Economics, 9, 52337

Roper. S., Ashcroft, B., Love, J. H., Dunlop, S., Hofmann, H. and Vogler-Ludwig, K (1996) Product Innovation and Development in UK, German and Irish Manufacturing, Northern Ireland Economic Research Centre/Fraser of Allander Institute, University of Strathclyde.

Rosenberg, N (1982) 'Inside the Black Box: Technology and Economics', Cambridge, Cambridge University Press

Song, X. M., Montoya-Weiss, M. M. and Schmidt, J. B. (1997) 'Antecedents and consequences of cross functional co-operation: a comparison of $\mathrm{R} \& \mathrm{D}$, manufacturing and marketing perspectives', Journal of Product Innovation Management, vol. 14, 3547

Soskice, D (1997) 'German technology policy, innovation, and national institutional frameworks', Industry and Innovation, 4, 75-96.

Souder, W. E. and Moenaert, R. K. (1992) 'Integrating marketing and R\&D project personnel within innovation projects: an information uncertainty model', Journal of Management Studies, 29, 485-502.

Stenbacka, R (2002) 'Microeconomic policies in the new economy', Finnish Economic Papers, Autumn 2002, 15, 2, 59-75.

Stoker, J I, Looise, J C, Fisscher, O A M, de Jong, R D (2001) 'Leadership and innovation: relations between leadership, individual characteristics and the functioning of R\&D teams', International Journal of Human Resource Management, $12,1141-1151$.

Streeck, W. (1989) Skills and the limits of neo-liberalism: the enterprise of the future as a place of learning, Work, Employment and Society, vol. 3, 89-104 
Streeck, W. (1992). Social Institutions and Economic Performance: Studies of Industrial Relations in Advanced Capitalist Economies, London, Sage

Topkis, D M (1998) Supermodularity and complementarity, Princeton University Press, Princeton NJ.

Topkis, D M. (1978) 'Minimizing a Submodular Function on a Lattice', Operations Research, 26, 305-321.

Tushman, M L., and Romanelli, E "Organizational Evolution: A Metamorphosis Model of Convergence and Reorientation.” In L.L. Cummings and Barry Staw (eds.) Research in Organizational Behaviour, 7:171-222, 1985.

Veugelers, R. and Cassiman, B. (1999) 'Make and buy in innovation strategies: evidence from Belgian manufacturing firms’, Research Policy, 28, 63-80.

Von Stamm, B (2003) Managing Innovation, Design and Creativity, John Wiley and Sons, London.

Wagner, J. (2001). 'A Note on the firm size-export relationship', Small Business Economics, 17, 229-237.

Walker, W (1993) 'National Innovation Systems: Britain', in Nelson, R R (ed) National Innovation Systems: A Comparative Analysis, Oxford University Press, 1993.

West, M (2002) 'Sparkling Fountains or Stagnant Ponds: An Integrative Model of Creativity and Innovation Implementation in Work Groups', Applied Psychology, 51, $355-424$.

Zeller, C (2002) 'Project teams as means of restructuring research and development in the pharmaceutical industry', Regional Studies, 36, 275-289.

Zenger, T (2002) 'Crafting internal hybrids: complementarities, common change initiatives, and the team-based organization', International Journal of the Economics of Business, 9, 79-95. 